\title{
The German Bruderschaften as Producers of Late Medieval Vernacular Religious Drama
}

\section{RALPH BLASTING}

Nearly two hundred manuscripts of German vernacular religious plays are known to exist. Their designation as Medieval has more to do with their style and intent than with their chronological distribution, since the texts are dated from roughly 1230 to as late as 1685 . Bound to Catholic tradition, these plays maintaincd religious dramatic practices in societics which were otherwise being affected by the changes of the sixteenth century. Their production reached its peak between 1450 and 1550-the same period during which the lay religious confraternities became numerous and popular. The connection inspires ready answers to questions about the financing and organization of these civic productions, but definitive explanations are obscured by a lack of archival evidence and the incomplete detail of those records which have survived.

Following a summary of what is known about the German confraternities (the Bruderschaften) in relation to religious drama, this paper offers a more detailed look at two locations: the south-west German town of Künzelsau, where the Brotherhood of St. John the Baptist (St. Johannes Bruderschaft) contributed to Corpus Christi festivities between 1474 and 1521; and Vienna, where the Corpus Christi Brotherhood (Gotleichnamsbruderschaft) seems to have been the primary producer and organizer of plays and processions on its namesake feast day.

The recent publication of two reference works in the field of German religious drama encourages investigation of the subject from broader perspectives than had previously been practical. Rolf Bergmann's Katalog der deutschsprachigen geistlichen Spiele und Marienklagen des Mittelalters (Munich: Beck, 1986) provides detailed descriptions of all the known

Renaissance and Reformation / Renaissance et Réforme, XXV, 1 (1989) 1 


\section{2 / Renaissance and Reformation}

manuscripts, along with outlines and overviews of their content and structure. Bernd Neumann's Geistliches Schauspiel im Zeugnis der Zeit (2 vols. [Munich: Artemis, 1987]) includes over 3,700 items related to religious dramatic performance, transcribed from archival sources in over 200 locations throughout the German-speaking areas. Together, the two works present broad empirical evidence of vernacular religious theatrical activity in German society from the thirteenth through the seventeenth centuries.

An investigation of the Bruderschaften as producers reveals a diversity of activities which makes generalizations-at least at this stage-difficult if not impossible. The lack of archival evidence may permanently prohibit a full picture of the accomplishments of the German confraternities. Even the evidence which does exist argues against a tidy explanation of their functions, since they seem to have fulfilled different purposes in different places. Where plays were performed, a confraternity may have been the sole producer, or have contributed to a production only cooperatively, or not have participated at all. Most locations supported several confraternities, and their relations to one another, to the craft guilds, to the Church, and to the municipal government are often unclear. It is rare that sufficient records from all of those sources have survived from a single location.

It is nonetheless possible to present some preliminary findings which reveal the extent to which these organizations might have been involved in theatrical activity. The Künzelsau records of the Brotherhood of St. John indicate sporadic contributions between 1474 and 1521, which suggest a connection to, but not the primary support of, the Künzelsau Corpus Christi Play. ${ }^{1}$ The records of the Viennese Corpus Christi Brotherhood include detailed references to virtually every aspect of dramatic production during the years 1499 to 1534 , suggesting that the confraternity was the primary producer of Corpus Christi presentations, especially between 1504 and 1512. My evaluation of the Vienna accounts is based on the published findings of Neumann and Hadamowsky, who have listed only the references to drama. $^{2}$ Although the expenditures for plays were extensive, I cannot comment on what proportion of the confraternity's annual finances they represent. I have, however, had the opportunity to view the Künzelsau accounts in their entirety, which has allowed some insight into the other concerns of the confraternity. ${ }^{3}$ But before we approach the records themselves, it will be helpful to consider more precisely what the German Bruderschaften were, the types of plays they were likely to support, and why they would venture to produce drama at all. 
First, the term Bruderschaft requires clarification. It refers here to the religious confraternities, and should not be confused with the Zünfte or Gilden. A Zunft was a craft guild, while the term Gilde seems usually to refer to a merchant guild. ${ }^{4}$ The terms Bruderschaft and Zunft both occur frequently-and sometimes interchangeably -in the records of performance.

The plays produced by the confraternities included those connected with the Easter season (the Passion, Resurrection, and related events), Corpus Christi plays, Christmas plays, plays in honour of particular saints, and various types of processions. ${ }^{5}$ But how did the performance of drama correspond to the purposes of the confraternities? In his study of the diocese of Würzburg, Robert Ebner identifies the confraternities as "societies in which the religious goals stand in the foreground." 6 A primary activity was the financing of special masses which were to be said for deceased members, either individually or collectively. It was extremely important for members to attend these memorial services, as well as to participate in all funcral and burial rites. ${ }^{7}$ A main advantage of the confraternities, however, was that their membership was not restricted to any single social group. Anyone who was deemed acceptable (i.e. morally upright), and who could afford an initiation fee and annual dues or contributions in kind, was eligible to join. ${ }^{8}$ The stark increase in the number and popularity of the confraternities has generally been attributed to the increase in lay piety which peaked during the late fifteenth and early sixteenth centuries. ${ }^{9}$ They seemed to offer the perfect opportunity to gain extra grace in the form of special masses and even indulgences; almost everyone belonged to at least one, and some joined several. ${ }^{10}$

The confraternities were inherently religious, and the drama which they produced was celcbratory in nature. The religious feast days were integral to the social life of the community; that the confraternitics participated in and eventually produced processions and plays is therefore not difficult to understand. A confraternity's inclusion in civic performances asserted and enhanced its role and significance within the community. In fact, the sequence according to which various groups were organized in procession became a sign of their relative importance. ${ }^{11}$

A major attraction of membership in a confraternity was the right to a place in these displays. Then, as now, people wanted to be included in, and to contribute to, communal activities. The Church, mainly through local bishops, supported the organizations by granting indulgences to those who participated, making membership even more attractive. Since members paid 


\section{4 / Renaissance and Reformation}

initiation fees, annual membership fees, and extra fees for special masses, increased membership naturally enhanced revenues. Money spent to produce plays may, in the long term, actually have generated a profit, although it is at present unclear how often this was true.

A final note on the Church's support of the confraternities is that Church approval was not immediate. The hierarchy was at first sceptical, fearing that the popular organizations would fragment the parishioners, and that control by the central administration would weaken as local piety-and loyalty-grew. It may be that the public processions and plays helped to change the Church's attitude. Obviously, Corpus Christi and Passion plays were living illustrations of Catholic dogma. The drama was the mass medium of the Middle Ages, and religious drama was the epitome of the genre at least to the end of the fifteenth century. More effective than the drama's demonstrative capabilities, however, was the participatory nature of the performances. Participation encourages conformity in a very tangible way. It is one thing to hear a clergyman describe the suffering of Christ, or even to witness its representation on stage; it is quite another to take part in that representation, in the role of Christ himself, Pilate, a soldier or an apostle, or as a set-builder, costumer, or musician. Few would disagree that direct involvement in ceremonial drama more effectively reinforces faith than does passive observation.

These general notes on why the confraternities produced drama do not bring us very much closer to an understanding of how the plays were produced, or of what forms they took. The financial accounts which have survived indicate that the confraternities kept very detailed records of their expenditures, making the accounts promising sources of information about late Medieval theatre. The fact that relatively few have survived is all the more lamentable in light of the significance of those which have.

Surviving descriptions of Corpus Christi processions often list the religious confraternities as participating figural groups, alongside the craft guilds and the clergy. In Bozen, the Brotherhood of St. Anne walked sixth in the procession, representing the family of its patron saint ("das Geschlächt Sant Anna"), and was immediately followed by the Brotherhood of St. Jacob, which represented the Annunciation to Mary. In Zerbst, the figural group of the Brotherhood of the Afflicted (Bruderschaft der Elenden) included the fourteen Nothelfer, the Christ child in white, St. Wendelinus, and a shepherd. The Corpus Christi Brotherhood presented Saints Catherine, Margaretha, Barbara, Dorothea, and other virgins, "as many as can 
be." Sometimes confraternities were founded for the express purpose of organizing plays. In Augsburg in 1484, the clergy of the Holy Cross ("zy dem heyligen creutz") requested permission to establish a Bruderschaft for the purpose of presenting a Corpus Christi procession, as they had already done for one or two years. Permission was granted by the clergy of the cathedral only after they were assured that the procession would not distract from the ceremonies in the cathedral itself. ${ }^{12}$

In most cases, the records of the confraternities give much more detailed information about their expenses than do comparable Church or municipal accounts. A typical priory record from Bozen reads: "Item expense to the carpenters in the brotherhood as assistance for Corpus Christi, 8 Bern $\mathrm{h}$ [eller]." 13 We know that the parish helped the carpenter's guild (or the carpenters in the confraternity?) with a financial contribution relating to Corpus Christi, but this tells us nothing about what the money was used for. A closer look at some accounts from confraternities in Künzelsau and Vienna give us a better idea of the materials and procedures required in the production of the plays.

The accounts from the small, southwest German town of Künzelsau seem to be typical of a German confraternity, as far as we can determine what was "typical" from the few accounts which have survived. The town had at least two, and perhaps three confraternities, and was the home of the Künzelsau Corpus Christi Play. Financial accounts survive from the confraternities of St. Wolfgang and St. John the Baptist, with one folio booklet indicating a confraternity of the Virgin Mary. ${ }^{14}$ Possible references to performance appear to occur only in the accounts of St. John, and even then they indicate that these activities were only a small part of the confraternity's functions. Of the thirty-three folio booklets of accounts ranging from 1475 to 1558 , records of performance occur in only six: 1475 , $1476,1507,1509,1511$, and 1522 . Neumann has reprinted sixteen items which he believes may relate to performances (nos. 1998-2005, 2008-2016), all of which had been previously published by Albert Schumann or Peter Liebenow. ${ }^{15}$ Some of the entries are detailed enough to relate to sections of the Corpus Christi play text.

The following items appear consecutively on fol. $2 \mathrm{r}$ of the account book dated 1475:

\section{Neumann no.}

[1998] 2 Bd we spent for paper for the procession.

[1999] 3 Bd for linen which was used for the dragon. 
[2000] $5 \mathrm{Bd}$ for 3 skins to the tanner for the crowns.

[2001] $15 \mathrm{Bd}$ to the gentlemen as we had the procession. ${ }^{16}$

Payments for paper occur throughout the records published by Neumann, including a later entry for Künzclsau which reads "Item 1 Bd for paper for the play." 17 Some records indicate that the paper was used either for copying out the entire play script, or for writing out individual parts for actors. The distinction between the terms "procession" and "play" was not definitive: the narrator of the Künzelsau Corpus Christi Play is indicated in the text as both "Rector Processionis" and "Rector Ludi," and the text itself is labelled "Registrum processionis corporis Cristi."

Items 1999 and 2000 are good examples of the detail often found in the accounts of the confraternities. "Linen ... for the dragon" is an unambiguous reference to a theatrical creation. The item does not mention a dragon's clothes or costume, so it is safe to assume that the dragon was a stage property, not an actor dressed as a dragon ( $c f$. no. 2012: "for material . . . for devils" clothes" ["fur thuch . . . fur theuffels cleider"]). Although the accounts do not specify where or when the dragon appeared, the Künzelsau text does include a dragon which accompanies St. George in the "Procession of Saints."18

In the same way, item no. 2000 gives details of an expense, but stops short of providing a definite connection with the play script. Paying the tanner for three skins for the crowns calls to mind the three magi. Although Licbenow has suggested that the crowns were lined with fur (interpreting "fel" as "pelt"), ${ }^{19}$ it is more likely that the crowns themselves were fashioned out of leather. This is more in keeping with the work of a tanner, and would have resulted in lightweight and durable costume pieces which could have been easily gilded and decorated.

The final item in this series refers to a procession, but does not indicate what the money was spent on. "Dy herrn" suggests gentlemen of higher social status, since fellow actors or confraternity members were usually referred to as Gesellen. In the Künzclsau accounts, expenses incurred by members are usually formulated collectively ("we spent" ["haben wir geben"]; $c f$. nos. 1998, 2003-04) or impersonally ("one spent" ["hat man geben"]; $c f$. nos. 1999, 2002). The "herrn" may have been the Chorherren (canons) of the parish church of St. John the Baptist, who almost certainly would have participated in the Corpus Christi celebration.

Four other items of particular interest for their detail occur in the accounts from 1507, 1509, and 1511: 
Neumann no.

[2008] 1 gulden $3 \mathrm{~B}$ to the painters of St. John's coat and to repair other things and [to the painters] of the lamb.

[2009] 3 B $6 \mathrm{~d}$ for linen for the coat and for a wig to go with it.

[2012] $10-1 / 2 \mathrm{Bd}$ for cloth to the tailors, also to the painters for devils' clothes and to improve other things on John the Baptist [Day].

[2014] 2 gulden 1 ort given to the painter for the clothes of the devil and pope, all added together. ${ }^{20}$

Payments to painters for decorating cloth or costumes are common in Medieval records of performance. ${ }^{21}$ Item 2008 indicates that John the Baptist and his attribute, the lamb, were given special attention, which is not unexpected in the accounts of the Brotherhood of St. John. The next item reveals that the confraternity purchased material for John's coat and for a wig to go with it. ${ }^{22}$ Items 2012 and 2014 also record payments for cloth and to the painters for decorating it. In no. 2012 we see that the painters and tailors worked together on devils' costumes, while no. 2014 indicates that the painters decorated costumes for the devils and for the "pope" who speaks the epilogue of the play. All of the figures mentioned in these account items appear in the text of the Künzelsau Corpus Christi Play, and all would have been deserving of decorative costumes.

It is clear from the Künzelsau accounts that the confraternity of St. John did not support the Corpus Christi play by itself. As detailed as the individual items might be, they do not nearly account for all of the costumes, properties, and other costs which would have been associated with the performance. Moreover, if we look at these items in the context of the other expenses of the confraternity, we see that they were a minute portion of the annual totals. The expenses in the 1475 account fill four columns, and contain some sixty-five separate items totalling roughly 43 gulden. The five line items listed by Neumann (nos. 1998-2002) comprise approximately 3.5 percent of the total expenses for the year. For the other accounts containing records of performance, the percentages are even lower: in 1476, only one item relates to performance; in 1507 there are two entries; in 1509, one; in 1511 , two; and in 1522, one item.

The other expenditures of the confraternity encompass a range of activities, most of them relating to special masses and maintenance of the church. Payments "per presentz" were probably made to the local clergy for their attendance at memorial masses for former members of the confraternity. Other items in the 1475 account book mention payments for 
candles (fol. 1v), maintenance of a vineyard (1v), repairs to a church window $(2 \mathrm{r}, 2 \mathrm{v})$, and payments to the schoolmaster (or perhaps someone named "Schulmaister") for writing (3r). The accounts from St. Wolfgang are similar, and apparently contain no references to theatrical performance at all. ${ }^{23}$

The Kunzelsau accounts, then, seem to give us a view of a more or less typical small-town confraternity. The main concern of the Brotherhood of St. John was the spiritual welfare of its members. It contributed to the maintenance of the church building and of church services, one of which was the Corpus Christi celebration. The records which relate to religious performance confirm that the confraternity was involved in these activities, but that they constituted only a minor aspect of the organization's finances. The lack of any parish or municipal records from the same period in Kunzelsau prevents a more complete picture of the production of the Corpus Christi play text.

From Vienna, surviving accounts of the Corpus Christi Brotherhood (Gotleichnamsbruderschaft) reveal a much fuller involvement in religious drama. The accounts from the years 1499-1534 are fairly complete, and suggest that the confraternity had been responsible for virtually all aspects of performance on the Feast of Corpus Christi. ${ }^{24}$

The Corpus Christi confraternity had existed in Vienna at least as early as 1445 , but was reincorporated in conjunction with the craft guild of the joiners (Tischlerbruderschaft) in 1497. This would not have been completely unexpected, since by 1486 the woodcarver Wilhelm Rollinger (now known for his work on the choir stalls in St. Stephan's cathedral) was also the director of the annual Corpus Christi procession. ${ }^{25}$ The confraternity's attachment to the craft guild, along with special financial patronage from the mayor's office, allowed the rapid expansion of production activity in the early sixteenth century. Unlike the Künzelsau records, I have had access only to the material relating to dramatic performance, as published by Neumann and Hadamowsky. Although I am therefore unable to put them into perspective, the records rclating to drama-especially from 1504 to 1513-reveal just how involved a confraternity could become in the production of civic/religious spectacles.

The first item for a "play on Corpus Christi day" ("spil an goczleichnamstag," [no. 2813]) occurs by itself in 1499. For each of the years 1499 to 1503, Neumann lists a single item, usually for food and drink for participants in the play, the cost of which increases steadily from $13 \mathrm{Bd}$ to $2 \mathrm{lb} 5$ B 17 d. For 1504, five items are listed. The confraternity was still 
paying for food and drink, but it also paid a tailor for a coat and for "hässugken" (?), a dyer to colour them, an armourer to polish the armour worn in the play, and a seamstress for making various articles of clothing (nos. 2820-23). In 1505, the number of line items for the play had increased to nineteen, and the accountants for the confraternity began including a separate total for the play's expenses. In 1505 it was 36 lb 6 B 12 d ("Summa ausgeben auff das spil facit $36 \mathrm{lb} 6$ B 12 d" [no. 2843]). Expenses included the usual ones for food and wine (nos. 2841-42), as well as payments to carpenters for four stages and six crosses, and wages to day-labourers for carrying material to the performance site, erecting the stage, and dismantling it after the performance (nos. 2825-27, 2834). The confraternity also paid for necessary materials, such as various forms of wood, boards, and battens ("holcz," "ladn," "lattn"), and at least four different types of nails ("verschlachnagl," "schintlnagl," "lattnagel," and "helbertnagl" [nos. 2829$33,2838])$. One of the most intriguing payments for that year went to Hanns Tenndler "for colouring Herod and for repairing him" ("von Herodes punt $\mathrm{zu}$ machen und zu pessern" [no. 2840]). This may relate to the inventory of 1513, in which the materials belonging to Herod and Pilate include "eleven coloured stakes, well ornamented in the Turkish style, with linen" ("Ainlef razisch püntt, wolgczicrt auf dic türkisch art, mit leinbat" [no. 3017]). The account for 1505 begins to indicate that the confraternity was responsible for most of the details of performance.

The confraternity's control of such details continued in 1506 and 1507. In 1506, it bought food and drink, wood, nails, and paid the "painters and joiners [of the] Mount of Olives, and what goes with the angel, and for making the crosses, and for painting [what was] new." 26 Expenses are also listed for fourteen shirts for soldiers (no. 2875), to the tinsmith for spears (no. 2883), and finally several items for writing expenses, including one "for writing the register for the play, for paper for the general requirements of the play, $2 \mathrm{lb} 2 \mathrm{~B} 12 \mathrm{~d}$." 27 In total, the account for 1506 includes forty items for the play, amounting to $61 \mathrm{lb} 3$ B $28 \mathrm{~d}$ (nos. 2854-94). The account for 1507 includes similar entries, although the thirty-five items add up to only $33 \mathrm{lb} 15 \mathrm{~d}$. Costs for food, lumber, nails, and labour remain more or less constant, and there was an additional expense "to the writer, who wrote the verses to the play and other necessary things." 28 Expenses for costumes and properties were generally lower in 1507 , although some money was spent to outfit Judas and the devils: 
For the clothes of the devils and Judas, to the tailor for making them and to the painter for painting the same as well as two faces [masks?] and several firearms red, $1 \mathrm{lb} 3 \mathrm{~B} 6 \mathrm{~d}^{29}$

The years 1504-1507 saw annual and substantial payments for virtually all aspects of the play, suggesting that the confraternity was the primary, if not the sole, producer of the spectacle.

After 1507, the records seem to indicate a slightly different type of Corpus Christi celebration. In 1508 and 1509, no play expenses were recorded. The records from 1510 to 1512 include eleven to fifteen line items annually, amounting to expenses of eighteen to thirty pounds for the plays. But the expenses are now largely broken down into payments for four large "groups" or "squads" of performers (Rotten), each of which had one leader who was responsible for its organization and expenses. In 1510, the groups were established as: (1) God with his attendants, numbering fifty persons; (2) the "Jewish school" (Sinagoga and his followers), with sixty members; (3) men-at-arms on horseback (not numbered in 1510, but including fifty-seven men in 1511, fifty-six in 1512); and (4) eighty foot-soldiers. ${ }^{30}$ The leaders of these groups were reimbursed for food and drink expenses for their groups, while the confraternity paid directly for costumes and properties. The expenses for 1511 and 1512 follow the same pattern, and suggest that the "play" on Corpus Christi had become more of a figural procession. ${ }^{31}$ Payments for wood, nails, carpenters, and the construction of the stage have disappeared, and therê are no further payments for writing out the verses. Moreover, the formulation of four processional groups of forty to sixty members each would itself have strained the organizational capacity of a director; to attempt to stage a play at the same time would have placed excessive demands on both performers and spectators.

The years 1513-1515 have yielded no records of performances in Vienna. From 1516 to 1534 , the confraternity sponsored a procession every year (except 1529, when it was cancelled due to rain), each of which was organized in the same way. The processional groups appear in the accounts each year, although the numbers of participants varied, and occasionally certain groups were eliminated altogether. The most expensive (and presumably the most elaborate) procession was held in 1519 , when all four groups were included and the expenses totalled 37 lb 2 B 24 d (Neumann nos. 3105-24), still far less than the expenses for the play in 1506 (see above). The leanest year seems to have been 1528 , when the procession included only one group, and cost $1 \mathrm{lb} 4$ B $12 \mathrm{~d}$ (Ncumann nos. 3282-86). 
Before we leave the Vienna records, we cannot afford to overlook one surviving document: the inventory of all materials held by the confraternity as drawn up by Wilhelm Rollinger and Matheus Heuberger in 1513. To list each item separately here is unnecessary, but a brief summary makes it clear that the confraternity possessed everything required to mount a performance. The list includes three crosses "to be used ... on Corpus Christi" ("so man braucht ... an gotsleichnambstag" [no. 3003]) and literally dozens of pieces of armour and weaponry (no. 3004). That which belonged to God with his attendants (in the procession) included a Mount of Olives, a pillar to which Christ was bound, a red cloak (for the "ecce homo"), a sponge on a pole, cloaks for Mary and John, and shirts for the two thieves. Mary Magdalene's wig is listed, with a specific note that "Master Wilhelm [Rollinger] had promised that it would never be used for worldly enjoyment or honour, but only for the honour of God. Where one should wish rather to use it in another way, one should sooner burn it." 32 Other costumes and properties included those belonging to the twelve apostles, Simon of Cyrene, angels, Pilate, Herod, Annas, Caiaphas, Sinagoga, foot-soldiers, and menat-arms. The armour was kept in four trunks. Finally, the inventory notes that "a register with verses, in which is written the entire Passion" was in the possession of Wilhelm Rollinger. ${ }^{33}$ The text has never been accounted for.

Why this inventory was written in the first of three years when no play or procession was sponsored by the confraternity is not clear. Perhaps the various properties and set pieces which had been used in 1504-1507 had remained in storage as the staged play became the figural processions of 1510-1512. The inventory may represent the confraternity's assessment of its stock, to determine which pieces were useful, and which obsolete. Whatever the reason, the inventory is an impressive list of the trappings of a late Medieval religious play. The fact that all of the material belonged to the confraternity is further evidence that it was the sole producer of the Corpus Christi spectacle.

Neumann's published records of performance allow a preliminary overview of the connection of the German Bruderschaften to dramatic activity in the late Middle Ages. This brief investigation of the records from Kunzelsau and Vienna has revealed the varying degrees to which a confraternity might have become involved in production, but a clear picture of the confraternities' connections to drama requires careful evaluation of all available archival sources. If the Künzelsau Brotherhood of St. John 
only partially sponsored the Corpus Christi play, who supplied the rest of the funding? Did the Vienna confraternity produce the Corpus Christi play entirely on its own? If not, how were other confraternities, the municipal government, and St. Stephan's itself involved? Questions such as these can only be answered through localized studies; for now, generalizations remain elusive.

\section{University of Toronto}

\section{Notes}

1 Ms. 1479; ed. Peter K. Liebenow, Das Künzelsauer Fronleichnamsspiel, Ausgaben deutscher Literatur des 15. bis 18. Jahrhunderts, Reihe Drama 2 (Berlin: de Gruyter, 1969). All references to the play will follow this edition.

2 Neumann, Geistliches Schauspiel, item numbers 2777 to 3331. We will be most concerned with nos. 2813-3324, the accounts of the Corpus Christi Brotherhood from 1499 to 1534. These were first transcribed and published by Franz Hadamowsky, Mittelalterliches geistliches Schauspiel in Wien 1499-1718, Quellen zur Theatergeschichte 3, Jahrbuch der Wiener Gesellschaft für Theaterforschung 23 (Vienna: Verband der wissenschaftlichen Gesellschaften Osterreichs, 1981). Further references to Neumann will be cited by item number: "Neumann, no. 000."

3 I wish to thank Herrn Riedinger of the Künzelsau Bürgermeisteramt, archivist Herrn Jürgen Rauser, and especially his assistant Herrn Stefan Kraut, for their generous assistance during my research in Künzelsau in June. 1986.

4 The appearances and uses of the terms Gilde and Zunft in historical records are not always clear. For a discussion of the socio-historical and semantic issues, see Ernst Cordt, Die Gilden. Ursprung und Wesen, Göppinger Arbeiten zur Germanistik 401 (Göppingen: Kümmerle, 1981).

5 One of the greatest difficulties posed by the performance records is the determination of exactly what activity was being recorded. The distinction between procession and play was not at all definite, and the dramatic structures of the texts which have survived reveal mixed forms. For detailed discussions of processional forms, see Neil C. Brooks, "Processional Drama and Dramatic Procession in Germany in the Late Middle Ages," Joumal of English and Germanic Philology 32 (1933): 141-71; and Elizabeth Wainwright, Studien zum deutschen Prozessionsspiel. Die Tradition der Fronleichnamsspiele in Künzelsau und Freiburg und ihre textliche Entwicklung, Münchener Beiträge zur Mediävistik und Renaissance Forschung 16 (Munich: Arbeo-Gesellschaft, 1974).

6 "Vereinigungen, bei denen die religiöse Zielsetzung im Vordergrund steht." Robert Ebner, Die Bruderschaftswesen im alten Bistum Würzburg, Forschungen zur fränkischen Kircheund Theologiegeschichte (Würzburg: Echter Verlag. 1978), pp. 43-67, here p. 53.

7 In addition to Ebner, pp. 43-67, see Hadamowsky, p. 10, and Rolf Kiessling, Bürgerliche Gesellschaft und Kirche in Augsburg im Spätmittelalter, Abhandlungen zur Geschichte der Stadt Augsburg 19 (Augsburg: H. Mühlberger, 1971), p. 292.

8 Both Hadamowsky (pp. 10-11, 24-73) and Neumann (nos. 2818 ff.) include certain items of income for the Corpus Christi Brotherhood which indicate initiatory or annual contributions by members. Women were allowed to join, but are usually mentioned along with their husbands (see Neumann, nos. 2818, 2896, 2900, 2901, 2979).

9 Ebner, pp. 23-27; Kiessling, p. 292; Wilfried Reininghaus, Die Entstehung der Gesellengilden im Späımittelalter, Vierteljahrschrift für Sozial- und Wirtschaftsgeschichte, Beihefte 71 (Wiesbaden: Steiner, 1981), p. 111 and n. 651: Gertrud Rücklin, Religiöses Volksleben des ausgehenden Mittelalters in den Reichsstädten Hall und IIeilbronn. Historische Studien 226 (Berlin: Emil Ebering 1933, repr. Kraus 1965), pp. 126-37. 
10 Ebner, pp. 25-26; Rücklin, p. 136.

11 Reininghaus, pp. 141-43.

12 Neumann, nos. 35/1-3; see also Kiessling, p. 293.

13 "Item ausgeben den zimerleiten in der bruederschafft zu einer hilff Corporis Kristi $8 \mathrm{~h}$ perner" (Neumann, no. 525). The "h" stands for Heller, a type of coin.

14 Künzelsauer Stadtarchiv sig. R1, Heiligenrechnungen St. Wolfgang 1501-1552; sig. R3, Heiligenrechnungen St. Johannes 1475-1558. Neither series is complete. The account book catalogued as St. Wolfgang 1501 indicates that it was prepared by "Die heiligenpfleger unser lieben frawen" (f. Ir).

15 Albert Schumann, Zu S. xii u. xiii von A. Schumann, "Das Künzelsauer Fronleichnamsspiel vom Jahre 1479", extra leaf, dated August 1926, to be inserted in his edition of the play (Das Künzelsauer Fronleichnamsspiel vom Jahre 1479 [Öhringen: Verlag der Hohenloheschen Buchhandlung, 1925]): Peter K Liebenow, "Zu zwei Rechnungsbelegen aus Künzelsau," Kleine Schriften der Gesellschaft für Theatergeschichte 21 (1966): 11-13; "Das Künzelsauer Fronleichnamsspiel: Weitere Zeugnisse zu seiner Auffuhrung," Archiv für das Studium der neueren Sprachen und Literaturen 205 (1969): 44-47. Schumann's "extra leaf" includes five items not clearly related to performance, which Neumann has therefore not included. All of the published items have been reprinted, translated, and interpreted in R. Blasting, "The Künzelsau Corpus Christi Play: A Dramaturgical Analysis” (Ph.D. diss., U of Toronto, 1989), pp. 227-46. On some minor discrepancies in dating the records, see Blasting, pp. 231-32.

16 "Item 2 Bd haben mir geben umb pappeyer zu der processen" [1998]; "Item 3 Bd umb leynonnt; dy hot man genommen zu dem trachen" [1999]; "Item 5 Bd umb 3 fel dem gerwer zu den kronen" [2000]; "Item 15 Bd dy herrn verthon, do man dy processen gehabt hat" [2001]. The entries are quoted as in Neumann, who indicates variant readings by Liebenow and Schumann. The designation "Bd" distinguishes the silver penny (WeiBpfennig or Schillingpfennig) from the ordinary copper or black penny, represented simply as "d." See Peter Spufford, Handbook of Medieval Exchange, Royal Historical Society Guides and Handbooks 13 (Bury St. Edmunds: St. Edmundsbury Press, 1986), p. 239; Liebenow, "Weitere Zeugnisse," p. 45; Blasting, pp. 233-34.

17 "Item 1 Bd umb bappeyer zu dem spil" (Neumann, no. 2005). See also Neumann, nos. 564, 566, 2048-49, 2473, 2890, 2905, 2924, 2940.

18 Stage direction before line 4283.

19 Liebenow, "Weitere Zeugnisse," p. 46.

20 "I I 3 B maalern vom rock sant Johanns und ander thing zu pletzen und vom lemlin" [2008]; "3 B 6 d umb leinwat zum rock und umb har darzue" [2009]: "10-1/2 Bd fur thuch dem schneidern auch dem maalern fur theuffels cleider und ander ding zu bessert uff Johannis Baptiste" [2012]; "2 $\mathrm{n} 1$ ort dem maler geben fur die cleydern der theüffell und bepst, alls zusamen gerechnet" [2014]. An ort is $1 / 4$ of a coin's value, usually $1 / 4$ gulden (Neumann, p. 103). Neumann, who relied on the publications of Schumann and Liebenow, includes "zu machen" at the end of item 2008; the words are not found in the manuscript. Some confusion also surrounds item 2012, printed by Neumann as both 2012 and 2015. For more detailed explanations see Blasting, pp. 242, 244-45.

21 Cf. Neumann, nos. 54/1, 74, 88, 107, 1349, 1434, etc.; see also the Records of Early English Drama volumes (Toronto: University of Toronto Press, 1979-), especially York (edited by A. Johnston and M. Dorrell, 1979), Chester (edited by L. Clopper, 1979), and Coventry (edited by $R$. Ingram, 1981).

22 I have suggested elsewhere (diss., pp. 185-87) that the "coat" may have included a false head, which would have been required for the execution scene in the Künzelsau play.

23 At this time, I am relying (as did Neumann) on Schumann's and Liebenow's published findings, and on Archivist Jürgen Rauser's assurance that the accounts contain no further references to plays. My review of the manuscripts in Künzelsau substantiated this, but I have not yet studied all of the St. Johannes or St. Wolfgang accounts in complete detail. 


\section{4 / Renaissance and Reformation}

24 For full transcriptions of the records, see Neumann, nos. 2777-3330 and Hadamowsky, pp. 24-73.

25 Hadamowsky, pp. 8-10. The choir stall was destroyed in 1945. See also Alois Nagler, The Medieval Religious Stage (New Haven: Yale University Press, 1976), pp. 97-102.

26 "Item von dem ollperig maller und tischler und was dem engl zugehort und von dem creuczn zu machen und von neuem anzustreichen $7 \mathrm{lb}$ " (Neumann, no. 2864).

27 "Item dy register zu dem spill zu schreyben, umb papir zu aller notturfft des spils 2 lb 2 B 12 d" (Neumann, no. 2890).

28 "dem schreuber, der die reymb des spils unnd ander notturfft geschriben hat" (Neumann, no. 2904).

29 "Von dem teufls unnd Judas klaid dem schneider davon zu machen unnd dem maler von demselben und auch zwain angesichtn unnd etlich puchsn rot ze malln geben $1 \mathrm{lb}$ 3 B 6 d" (Neumann, no. 2919).

30 Neumann, nos. 2948-51. For the numbers of soldiers on horseback in 1511 and 1512, see Neumann, nos. 2960, 2982.

31 See Hadamowsky, p. 14.

32 "Hat maister Wilhalbm versprochen, das zu dhainer weltlichen freid noch eer zu prauchen, alain zu der eer gottes. Wo man es aber in ander weg wolt prauchen, sol man es ee verprennen" (Neumann, no. 3013).

33 "Ain register mit reymen, darin verschriben der gannz passion, hat maister Wilhalm Rollinger" (Neumann, no. 3023). 